DOI: $10.2478 / \mathrm{v} 10122-011-0017-2$

\title{
ON THE INDO-EUROPEAN ORIGIN OF THE DUAL $N$-MARKER IN TOCHARIAN
}

\author{
KRZYSZTOF TOMASZ WITCZAK
}

\begin{abstract}
Aвstract: Krzysztof Tomasz Witczak. On the Indo-European Origin of the Dual N-Marker in Tocharian. Lingua Posnaniensis, vol. LIII (2)/2011. The Poznan Society for the Advancement of the Arts and Sciences. PL ISSN 0079-4740, ISBN 978-83-7654-173-0, pp. 123-127.

Purpose: In my paper I discuss the origin of the dual $n$-marker in Tocharian (Toch. B -ne, A - $\dot{m}$ ), which seems to denote natural pairs, as well as random twosomes. It is traditionally treated as an innovation of the Tocharian languages. Method: In my investigations I used the historical-comparative method. Results: Some residual facts attested in the different Indo-European languages (including Albanian, Old Prussian and Insular Celtic ones) demonstrate traces of the $n$-marker. Conclusion: The dual $n$ marker, preserved in Tocharian, is of Indo-European origin.
\end{abstract}

Krzysztof Tomasz Witczak, Department of Linguistics and Indo-European Studies, University of Łódź, Lipowa 81, PL-90-568 Łódź, ktw@uni.lodz.pl,krzysztof.tomasz.witczak@gmail.com

In his short paper on dual and "paral" forms in Tocharian Wolfgang KRAUSE (1955) tried to prove the statement that there is a semantic opposition between natural pairs and random ("okkasionell") alignments of two items, which is matched with a formal contrast: natural (or established) pairs are referred to by forms in Toch. B -ne (= Toch. A - $\dot{m}$ ), random "paral" groupings by forms without $-n e$.

KRAUSE's stand-point has been abandoned by W. WinTER (1962: 111-134 = 1984: 124$159)$, who rightly states that a number of ne-less items refer to natural pairs, e.g.

$$
\text { Toch. B mlyuweñc 'two thighs' ( }<\text { Toch. B mlyuwe 'thigh'); }
$$

Toch. B eś beside eś(a)ne 'two eyes', also in the compound yneś 'manifest, real' (literally 'in the two eyes') < Toch. B $e k$ sg. 'eye', A $a k$ 'id.'

Toch. B pauke (sic!) beside pokaine 'two arms', cf. Toch. A poke 'arm'.

Toch. B ken̄i beside kenīne 'two knees' (= Toch. A kanwem du. 'id.').

Werner WINTER concludes that, contrary to KRAUSE's opinion, the contrast between two semantic groupings (natural pair vs. random twosome) is not neatly reflected in the contrast of two formal classes; -ne was found to occur in a few forms which could not readily be demonstrated to refer to natural pairs [...], while -ne-less forms are attested for a considerable number of members of the natural-pair group: eś 'eyes', klauts 'ears', *pokai 'arms', maś 'fists', mlyu- 
weñc 'thighs', kenī 'knees', pai 'feet'. In most cases [...], ne forms exist beside -ne-less ones (WINTER 1962: $\S 5=1984: 111$ ).

The Tocharian B ending $-n e(=\mathrm{A}-\dot{m})$ seems to be recognized as a secondary addition, because the -ne-less forms can be safely analyzed as a complete duals, cf. eg.

Toch. B eś 'two eyes' < IE. *o(t) $k^{w} i-h_{l}$, cf. Lith. aki du. 'two eyes', OChSl. oči 'id.', Skt. akṣî̀ du. 'two eyes', Avest. aši ‘id.'. Also Gk. ő $\sigma \sigma \varepsilon$ du. 'two eyes' and Alb. sy pl. 'eyes', derived from Balkan-IE. * $o(t) k^{w} y \partial_{1}$, seem to belong here.

Toch. B pauke 'two arms' < IE. *bhā $\hat{g} h u h_{1}$ or *bhā $\hat{g} h u w-h_{1} e$, cf. Skt. bāh $\hat{u} \mathrm{du}$.

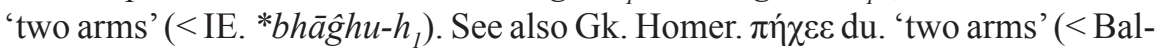
kan IE. *bhā $\left.\hat{g} h e w-\partial_{1}\right)$.

Toch. B maś 'two fists'< IE. *musti-h, $h_{1}$ cf. Skt. mușțî́ du. 'two fists'.

Toch. B kenī 'two knees' < IE. * $\hat{g} o ́ n u-h_{l}$, cf. Skt. jānū du. 'two knees'.

Toch. B. pai 'two feet'< IE. *pod- $h_{l} e$.

Consequently, WiNTER (1962: $\S 8=1984: 146-149)$ discusses the status of the dual marker $-n e$ in Tocharian B (or $-\dot{m}$ in Tocharian A) and its origin, comparing this marker with the so called secondary case endings ("they occur both as genuine suffixes and as member of nominal phrases with the rank of separate words", according to WINTER 1984: 148) and especially with the ending -na found in the plural of feminine nouns or adjectives such as śnona 'wifes' (< śana 'wife' < IE. * $\left.g^{w} e n V h h_{2}\right)$, rätrona adj. pl. fem. < ratre adj. 'red' $(<\mathrm{IE}$. $*\left[h_{1}\right]$ rudhros $)$. Finally, he reconstructs $*_{-n} \bar{o}$ for Toch. A - $\dot{m}$, and derives Toch. B -ne from *nōu.

Similarly to Winter, J. Hilmarsson (1989: 40-41) reviews the origin of the dual marker in Tocharian only on the basis of internal evidence. After concluding that "there is no particular reason to interpret B -ne, A - $\dot{m}$, as reflexes of an I.-E. *nō" (Hilmarsson 1989: 34), he prefers his own interpretation, according to which "an early Common Tocharian *nceyä $(<$ I.-E. *no-i) was enclitically used with dual forms". Consequently he suggests that “*-nceyä yielded *-nce through contraction” (HiLMARSSON 1989: 40-41).

In my opinion, the Indo-European origin of the dual $n$-marker in Tocharian can be proven on the basis of external evidence taken from Albanian, Old Prussian and Celtic.

\section{ALBANIAN EVIDENCE}

According to the traditional etymology, suggested many years ago by H. Pedersen, the Albanian term for 'eyes', $s y$ (nom. pl. and sg.), represents "a form of dual [...] related to Skt akșín, Av aši, Lith akì, Slav *oči” (OREL 1998: 405). The definite form of the singular number, syri (Tosk) or syni (Gheg), which represents also a dual formation from the phonological point of view, shows evidently an $n$-extension (Huld 1984: 113; Euler 1985: 107). Alb. (Gheg) sy-ni, (Tosk) sy-ri seems to derive from the singular-plural (originally dual) form sy 'eye' (= Gk. ǒ $\sigma \sigma \varepsilon$ du. 'two eyes' < Balkan-IE. *okw $y z_{1}$ ) owing with a nasal suffix (perhaps $*_{-}$noi). The eyes are generally treated as a natural pair, so the original dual form 
became the reason of the creation of a new singular form. The alternation of Alb. sy 'eye' (in the indefinite form) and syri (Tosk) / syni (Gheg) 'id.' (in the definite form) resembles a similar variation in Tocharian, cf. Toch. B eś beside eś(a)ne 'two eyes'.

Also Alb. gju, -ri (Tosk), -ni (Gheg) m. 'knee', pl. gjunjë (EULER 1981: 108) seems to be a late creation based on an original dual form (knees are treated as a natural pair) accompanied by a nasal suffix derived from the Indo-European dual marker. The Albanian term in question contains the root *glu-, dissimilated from PIE. * $\hat{g} n u$ - 'knee' (also * $\hat{g} e ́ n u-$, gónu-, * ĝnéu as in Lat. genu n., Gk. yóvv n., Goth. kniu n. 'knee') in the position before a different nasal, which belonged originally to the dual marker (PAlb. *-nai < PIE. *-noi). In other words, Alb. gju, -ri (Tosk) and -ni (Gheg) m. 'knee' should be compared with Toch. B kenine du. 'two knees' and Toch. A kanwem du. 'id.' (< PIE. * $\left.\hat{g} o n u h_{1}[e]-n o i\right)$.

It is possible to conclude now that the above-mentioned Albanian nouns contain traces of the dual marker $*_{-n o i}$.

\section{OLD PRUSSIAN EVIDENCE}

There are two items with the $-n V$-suffix in the Pomezanian dialect of the Old Prussian language, which are formally identical with $n V$-less forms in the Sambian dialect:

Pomez. (EV 80) agins (nom. sg.) 'ouge / eye' vs. Samb. *ackis f. sg. 'eye' (acc. pl. ackins);

Pomez. (EV 83) ausins (nom. sg.) 'ore / ear'vs. Samb. ausis f. sg. 'ear'.

It is hardly possible to assume, following W. SMOCZYŃSKI (1989: 32; 2000: 16-17), that both Pomezanian words agins and ausins are accusatives pl. in form (or pluralia tantum with the Low German ending -ens) particularly that both 'eyes' and 'ears' belong to the group of natural pairs. This is why I am inclined to treat them as derivatives from dual remnants. Now if we compare the Old Prussian dual forms of $i$-stem with the East Baltic and Slavic ones, then a curious marker -ns (probably *-nas) can be established in West Baltic, cf.

OPrus. (Pomez.) agins (<*akť + -nas) vs. Lith. aki du. 'two eyes', OChS1. oči 'id.', Pol. oczy, Russ. óči (< BSl. *akî̀ du.).

OPrus. (Pomez.) ausins (<*ausît+-nas) vs. Lith. ausì du. 'two ears', Pol. uszy, Russ. úši (< BSl. *aušlı du.).

The opposition between the West Baltic and East Baltic forms seems similar to or even identical with the situation observed in Tocharian and Albanian, cf. Toch. A aśäm, Toch. B eś(a)ne vs. Toch. B eś (both 'two eyes'), Alb. syni / syri vs. sy (both 'eye'). Formally, BSl. *akl du. corresponds to Toch. B eś (du.) 'two eyes' and Alb. sy pl. 'eyes' (all from IE. $\left.*_{o}(t) k^{w} i-h_{1}\right)$. On the other hand, OPruss. akins sg. 'eye' seems to be related to Toch. A aśäm, Toch. B eś(a)ne du. 'two eyes' and to Alb. syni/syri 'eye' (the definite form). It is clear, therefore, that the West Baltic languages, as well as the Tocharian and Albanian, demonstrated originally a number of parallel forms with the $-n$-marker and without it. It seems 
probable that the $-n$-marker was originally connected with the dual forms, but it was later used to create the singular forms.

During Colloquium Pruthenicum Primum (Warsaw, 30th September - 1st October 1991) I discussed the problem of the Albanian term for 'eye' with prof. Eric P. HAMP, the well known comparative linguist, the leader of the Indo-European studies and albanology. He did not exclude that Albanian shows the same nasal marker, which appears in the dual forms in the Tocharian languages. What is more, he expressed the opinion that Old Prussian (Pomezanian) agins 'eye' (if it is registered in nom. sg.) may be exactly compared with the definite form of Alb. syni / syri 'eye'. Both these words may be derivable from the dual form $*^{o} k^{w} t$ by means of an extension $-n V$ (where $V$ represents a unknown vowel).

\section{CELTIC EVIDENCE}

There is one term in the Celtic languages, which was recognized as a possible equivalent of Alb. gju 'knee' (pl. gjunjë), namely: Olr. glún n. 'knee' (< Goidelic Celtic *glünos < PCelt. *gnünos), MW. pen-lin, pen-glin (m. and f.), OCo. penclin gl. genu, MBret. penn-glin 'knee' (< Brittonic Celtic *penno-glünos $<$ PCelt. * $k^{w}$ enno-gnünos). It seems to contain the original dual and the dual $n$-marker.

In his dictionary Matasović (2009: 162) gives the following comment:

The transformation of PIE * $\hat{g}$ onu- into PCelt. *gnünos > Olr. glún is difficult to understand, but the etymology is beyond doubt. Long $* \bar{u}$ might reflect the old dual ending in $*_{-} u h_{1}$, and the cluster $*_{g l}$ - arose from * gn- in the zero-grade of the PIE root (the same change occurred, independently, in Albanian, cf. Alb. gju 'knee' $<*$ glun-). The first element of the compound attested in the Brit[tonic] languages is the word for 'head' $\left({ }^{*} k^{w}\right.$ enno-). Probably ${ }^{*} k^{w}$ enno-gnünos referred originally to knee-caps only (cf. the parallelism with the Eng. compound knee-cap).

It is highly probable that the Celtic term for ' $k$ nee' was rebuilt after the dual formation

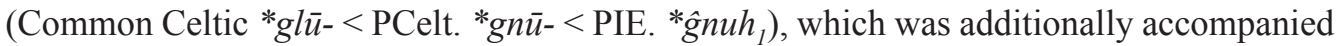
by the dual marker *-noi. On the basis of the original dual form *gnünoi 'two knees' $(<$ PIE. * $\left.\hat{g n u h} h_{1}-n o i\right)$ the ancestors of the Celts created a new singularized archetype *gnünos, later *glünos 'knee'. The same development must be postulated for the Albanian term for 'knee' (see above).

\section{CONCLUSIONS}

1. The Tocharian languages demonstrate the marker $-n e$ (Toch. B) or $-\dot{m}$ (Toch. A), which may be added to the original dual forms. The dual marker goes back to PIE. *-nō (according to Werner Winter) or to PIE. *-noi (according to Jörundur Hilmarson).

2. The residual forms, attested in Albanian, West Baltic and Celtic, seem to demonstrate that the same dual marker was used not only in the Tocharian languages, but also in some different idioms belonging to the Indo-European family.

3. The dual $n$-marker must be treated as an Indo-European archaism and not an early innovation of Tocharian. 


\section{REFERENCES}

Euler Wolfram. 1985. "Körperteilnamen im Albanischen und ihre Herkunft.” Indogermanische Forschungen 90, $104-122$.

Hilmarsson Jörundur. 1989. The Dual Forms of Nouns and Pronouns in Tocharian. Reykjavík: Jörundur Hilmarsson (Tocharian and Indo-European Studies. Supplementary Series, vol. 1).

Huld Martin E. 1984. Basic Albanian Etymologies. Columbus: Slavica Publishers.

Krause Wolfgang. 1955. "Zum Gebrauch des Parals und des Duals im Tocharisch." Zeitschrift für vergleichende Sprachforschung 72, 233-234.

Matasović Ranko. 2009. Etymological Dictionary of Proto-Celtic. Leiden-Boston: Brill.

Orel Vladimir. 1998. Albanian Etymological Dictionary. Leiden-Boston-Köln: Brill.

SMOCZYŃSKI Wojciech. 1989. “Эльбнгский словарь: эмендации, чтения и этимологии” [The Elbing Vocabulary: emendations, readings and etymologies]. In: Топоров 1989: 13-42.

SmocZYŃski Wojciech. 2000. Untersuchungen zum Deutschen Lehngut im Altpreussischen. Kraków: Wydawnictwo Uniwersytetu Jagiellońskiego.

Топоров В.Н. (ed.). 1989. Балто-славянские исследования 1987. Сборник научных трудов. Москва [Моscow]: Nauka, 13-42.

WiNTER Werner. 1962. "Nominal and Pronominal Dual in Tocharian." Language 38, 111-134.

Winter Werner. 1984. Studia Tocharica. Selected Writings. Poznań: Wydawnictwo Naukowe UAM.

Allatum die 25 mensis Maii anno 2011 